\title{
Psychological Distress in Urbanizing China: How Does Local Government Effectiveness Matter?
}

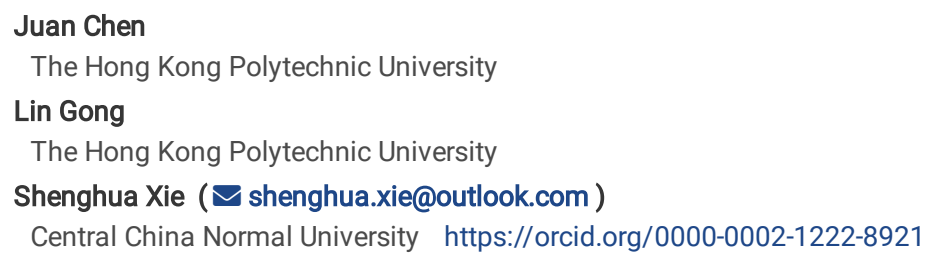

\section{Research}

Keywords: Psychological distress, Worries, Government effectiveness, Urbanization, China

Posted Date: December 8th, 2020

DOI: https://doi.org/10.21203/rs.3.rs-120636/v1

License: () (i) This work is licensed under a Creative Commons Attribution 4.0 International License. Read Full License 


\section{Abstract}

Purpose

This study investigates how the effectiveness of local government affects residents' levels of psychological distress in areas of China undergoing urbanization. We measure the effectiveness of local governments according to their success in promoting access to the social security system through distribution of social security cards among citizens. We hypothesize that higher local government effectiveness will reduce residents' psychological distress by alleviating worries about medical expenses and elder care.

\section{Methods}

Drawing on data from the 2018 Urbanization and Quality of Life Survey $(\mathrm{N}=3,229)$ conducted in 40 localities undergoing rural-urban transition, we estimate three-level mixed-effects regression models to test the research hypotheses, allowing random effects at the township/county and neighbourhood levels while controlling for a series of individual attributes.

\section{Results}

Local government effectiveness is negatively associated with residents' psychological distress: effective local governments alleviate worries about medical expenses and elder care, and thereby reduce psychological distress.

\section{Conclusion}

To reduce residents' worries and psychological distress during the process of rural-urban transition, it is essential to improve local government effectiveness, particularly in promoting residents' access to the social security system.

\section{Introduction}

The state of mental health has received growing attention as the level of urbanization continues to rise in developing countries. Studies have confirmed that psychological disorders are more common and complicated in urbanized areas [1]. While key individual, family, community, and environmental factors have been identified as causes for mental disorders during the process of urbanization [2], the role played by local government has not been taken into account. This is particularly important in China where both the scale and speed of urbanization have had an adverse effect on residents' mental health [3, 4], but the level of mental health literacy among the general population is relatively low, and people's preconceptions about mental disorders and treatments need to be greatly improved $[5,6]$. To fill this research gap, this study investigates how the effectiveness of local governments exacerbates or alleviates residents' psychological distress in areas of China undergoing urbanization.

\section{Government effectiveness}

Government effectiveness is one of the key indicators of good governance and a direct source of individual well-being [7-9]. According to the World Bank, government effectiveness can be broadly measured by "the quality of public services, the quality of the civil services and the degree of its independence from political pressures, the quality of policy formulation and implementation, and the credibility of the government's commitment to such policies [10]." Studies have examined the impact of government effectiveness on human welfare and well-being. Sacks and Levi, for instance, focus on the experience of citizens living in Africa where famine remains a serious threat [11]. In their study, a government's effectiveness is measured by its ability to facilitate reliable access to food for its citizens. If a government is effective, it will be able to deliver goods that individuals need to improve their social welfare. Government effectiveness is an important factor in combatting human trafficking [12]. In addition to the willingness to take action, a country must have the funds, institutional capacity, and human resources to implement an anti-trafficking policy. Government effectiveness also plays an important role in reducing child mortality, particularly in developing countries: those with more effective governments (i.e., competent bureaucracies and reliable public service delivery) are more efficient in providing health care services and, therefore, more likely to reach goals for health outcomes [13]

Some studies focus on the links between government effectiveness and subjective well-being. Scholars argue that there are positive links between government effectiveness and the subjective well-being of citizens, and most empirical evidence supports this claim [14]. The quality of service delivery is generally considered more important than the degree of democracy in determining well-being, although in developed countries where service delivery has reached sufficient levels, the degree of democracy also shows positive links to subjective well-being $[14,15]$.

Most studies of government effectiveness have been conducted at the national level: countries are viewed as consistent entities [16]. In recent years, scholars have attempted within-country comparisons, which demonstrate that cross-country analysis does not tell the whole story. There are many within-country variations that are, in part, the result of the effectiveness of lower levels of government [16, 17]. Liu et al., for instance, examine performance in public service delivery as one of the three key indicators of government quality in China and find that it has the strongest positive impacts on urban respondents' life satisfaction [15].

Survey-based measures of subjective well-being have been widely regarded as reliable indicators of human well-being in the literature on the effects of government [18]. The most widely used measure is a global cognitive assessment of happiness or life satisfaction [19]. Despite the growing literature on government effectiveness and subjective well-being, little research attention has been paid to measures of mental health, which is an important aspect of human well-being and is likely to be affected by government effectiveness as well.

\section{Urbanization in China: Providing a context}


Over half of the world population now live in urban settings, and it is projected that five billion people will do so by 2030 , and seven billion by 2050 [20]. Developed countries are already highly urbanized, so almost all of the urban expansion predicted will occur in developing countries [21]. A considerable body of evidence shows that having an effective local government is crucial in enabling efficacious urban planning, boosting development, and improving service provision and delivery, particularly in newly developed urban areas [22-24]. There is, therefore, an urgent need for scholars, policy-makers, urban planners, and service providers to understand the challenges associated with local governance, identify indicators of effective local government, and improve government effectiveness in localities undergoing rural-urban transition [25].

Following an agenda of territorial urbanization, the Chinese central government has established new cities, enlarged or merged existing ones, and eliminated others, in order to boost economic development and strengthen its power [26]. Between 1978 and 2010, the number of cities in China jumped from 193 to 658. As the cities proliferated, they also increased in size through extensive reclassification of previously rural land [27, 28]. During this process, counties (and county-level cities) were converted to urban districts, rural townships (xiang) upgraded to towns (zhen), and towns and rural townships reclassified as street districts (jiedao) [29].

The current leadership in China continues to implement policies to promote urbanization. The Chinese household registration system (hukou), which was introduced in the 1950s to ensure economic and social control, consistently favours long-term residents in urban areas [30, 31]. Without reforming the hukou and associated social insurance and welfare systems, further urbanization is likely to perpetuate unequal access to public services [32]. To address this disparity, in March 2014, the National New-Type Urbanization Plan was launched, emphasizing people-centred urbanization and heralding a new era of urban development [33]. The Plan aims to increase the percentage of the population classified as urban to $60 \%$ by 2020 , which would require relocating or reclassifying 100 million villagers. This goal was achieved before the final months of 2020: $60 \%$ of Chinese citizens are now living in towns and cities. The percentage is expected to rise to $70 \%$ by 2030 and $80 \%$ by 2050 [34]. In addition to increasing the urbanization rate, the Plan proposes to grant permanent and full urban status to 100 million new urbanites. It also aims to reduce rural-urban income and service disparities: the rural and urban social security systems will be integrated in order to narrow gaps in enrolment and access to services [35].

Despite these policy goals, scholars argue that the 2014 Plan was primarily designed to deal with the pressures of economic slowdown and to solve the problems created by past urbanization [35]. Local governments have been criticized for seeking financial gain through land sales rather than focusing on the general well-being of affected residents and communities [36]. The goal of making social security more equitable has not been realized: although enrolment reached 1.12 billion by March 2018 (representing $80.6 \%$ of the total population), huge variations still exist in access to the social security system [37]. Effective local governments take responsibility for securing residents' livelihoods by distributing social security cards and granting citizens easy access to the social security system.

The Chinese social security card is an all-in-one smart card that stores key personal information and provides the cardholder with access to a variety of government services. The card system relies on a central database that enables citizens to use the smart card to identify themselves, claim medical reimbursements, and make payments for health and other social services. The social security card system was piloted in Shanghai in 2001 . It was created to address the operational constraints experienced by local government agencies and also fulfilled the e-government directives of the central government. Access to the card was first limited to certain groups such as urban retirees and state employees [38], but since 2011, the social security card system has been expanded and implemented nationwide. Although the total number of cardholders keeps growing, there are striking disparities depending on locality [39].

We are using the promotion of social security card distribution as a measure of local government effectiveness for three reasons. First, nationwide social security card coverage is one of the main goals of the social security information system in China. Almost all local governments consider this issue at the top of their policy agenda and have initiated policies to address it [40]. Second, the social security card system provides a basis for standardized management, public service optimization, and rural-urban integration. The Shanghai municipal government, for example, was prompted by the introduction of the card to implement a city-wide information system to improve the service coordination among local administrative systems, including social security, public security, civil affairs, health insurance, and provident fund management [38]. The use of social security cards has improved the service quality and response speed of local governments [41]. Third, since September 2014, the e-certificate, which is based on the social security card system, has been established on a nationwide scale. The extended digital functions of the card include the ability to make inquiries and e-payments, and further boost e-government and the interactions between local governments and citizens [42].

Thus, the context of our study is China's implementation of the National New-Type Urbanization Plan. Our measure of local government effectiveness is its success in promoting access to the social security system through the distribution of social security cards during the process of rural-urban transition. We focus on the mental health status of residents of localities undergoing rural-urban transition and employ the Kessler Psychological Distress Scale (K10) as the outcome measure. We estimate three-level mixed-effects models to test the following research hypotheses.

\section{Research hypotheses}

Although it does not focus specifically on psychological distress, research has established positive links between government effectiveness and citizens' subjective evaluation of their life. Effective government can lead to higher subjective well-being among residents, both directly and indirectly. Directly, people are better off living in a context of effective government; indirectly, effective government allows people to achieve higher levels of other metrics and reduce worries that threaten their overall well-being [8]. Most empirical evidence supports the positive links between government effectiveness in service delivery and subjective well-being $[43,44]$. Yet exactly how government effectiveness affects residents' subjective well-being, and the magnitude of direct and indirect effects have not been demonstrated, particularly in the context of lower levels of government in developing countries undergoing urbanization.

In the case of China, scholars have expressed concern that the National New-Type Urbanization Plan downplays the challenges of regional heterogeneity and the effectiveness of local government [4,33]. Following the launch of the Plan, the National New Comprehensive Urbanization Pilot Program was implemented 
in 2014 [45]. The wide range of responses from the participating local governments revealed pressing concerns about the implementation and the effect of the Plan. Many local governments sought opportunities to obtain additional funding and land quotas for urban construction, and there were serious doubts as to whether these governments would make resident well-being their top priority [4, 32]. Relatively few local governments appeared committed to promoting public service and social welfare during the process of rural-urban transition, so as to enhance residents' mental health and reduce their psychological distress [15]. Based on these concerns and responses, we develop the main hypothesis:

Hypothesis 1: Local government effectiveness will have a direct effect on residents' mental health: residents of localities with higher government effectiveness will report lower psychological distress.

As noted, in addition to its direct effect, local government effectiveness may also affect residents' mental health indirectly. During the process of urbanization, individuals are separated from their traditional agricultural communities. They are required to deal with a more complex, ever-changing urban society, and rely on their own efforts to make a living and pursue self-development [46]. In places where access to urban social security system has not be secured, perceived risk and uncertainty about individual and family life are prevalent [3]. Scholars categorize worries as "micro-worries" and "macro-worries." Micro-worries refer to potential problems of individuals and their circle, whereas macro-worries are associated with problems in broader social contexts, such as race/ethnicity, social class, nation state, or even the world [47]. Studies have documented the detrimental impact of micro-worries on psychological well-being, leading to higher levels of distress [48]. Macro-worries, on the other hand, are not associated with mental health [47]. Based on these theories and empirical evidence, we develop a second hypothesis:

Hypothesis 2: Local government effectiveness will have an indirect effect on residents' mental health: localities with higher government effectiveness will alleviate residents' micro-worries related to social security and thus reduce their psychological distress.

\section{Data And Methods}

\section{The 2018 Urbanization and Quality of Life Survey}

The data for this study come from the Urbanization and Quality of Life Survey $(\mathrm{N}=3,229)$ that we conducted in 2018 . The survey targeted residents in 40 primary sampling units (PSUs), including 32 townships (street districts or towns) in newly urbanized areas and eight townships (towns or rural townships) considered to be potential sites of urbanization. Half of the PSUs were drawn from the list of the 2014 National New Urbanization Comprehensive Pilot Program [45]. The other 20 localities were selected from non-pilot areas using the Coarsened Exact Matching (CEM) technique [49]. After the 40 PSUs were carefully sampled, we created a detailed geographical information system (GIS) that aggregated information at the arc-minute level within each PSU and generated spatial sample frames of physical areas [50]. Because the townships were located in different counties, county-level cities, and urban districts, the 40 PSUs covered 40 county-level administrative units.

Within each PSU, we randomly selected four half square minutes (HSMs) of latitude and longitude as secondary sampling units (SSUs) -about the size of a rural village or urban neighbourhood. Within each SSU, we selected households for conducting the survey interviews. The target population was adults aged 18 to 75 , regardless of their hukou status, who had resided in the township for at least six months and in the household for more than 30 days. Within each household, one eligible respondent was chosen using the Kish grid. Ethical approval of research projects involving human subjects was obtained from the authors' home institute. The survey fieldwork was carried out from April to June 2018. Face-to-face interviews were conducted using the computer-assisted personal interviewing (CAPI) system. After data checking and cleaning, we obtained the final valid sample of 3,229 respondents with a response rate of $65.2 \%$. Post-stratification weights were developed to adjust the survey respondents to the 2010 China Township Population Census Data on key demographic variables such as gender and migration status [51].

\section{Measures}

\section{Psychological distress}

We administered the Kessler Psychological Distress Scale (K10), a ten-item self-reported questionnaire that measures respondents' psychological distress in the previous month. The validity of this measure has been tested in the Chinese context [52-54]. The Cronbach's alpha was 0.93 for the study sample. We took the sum of the scores on the ten items. The final scores ranged from 10 to 50, with higher scores indicating higher levels of psychological distress.

\section{Individual-level variables}

We included individual-level covariates in the analysis, including age, gender, marital status, education, occupation, party affiliation, household wealth, homeownership, hukou category, and migration status. We further controlled respondents' chronic health conditions, enrolment in medical and pension insurance schemes, and possession of a local social security card. Respondents were asked whether they worried about paying large medical bills if they get seriously ill and about not having elder care in the future. The latter two measures were used as mediating variables. Table 1 shows details of these individuallevel measures and their descriptive statistics. 
Table 1

Descriptive statistics of survey respondents and variable descriptions

\begin{tabular}{|c|c|c|}
\hline Variables & $\begin{array}{l}\text { Means or } \\
\text { percentages }\end{array}$ & Variable descriptions \\
\hline $\begin{array}{l}\text { K10 psychological distress } \\
\text { (mean) }\end{array}$ & $16.869(0.163)$ & Kessler Psychological Distress Scale (K10): $\min =10, \max =50$ \\
\hline Social security cardholder (\%) & $46.231(1.219)$ & Dichotomous: 1 = yes, $0=$ no \\
\hline Medical insurance (\%) & $91.680(0.621)$ & Dichotomous: 1 = yes, $0=$ no \\
\hline Pension insurance (\%) & $53.775(1.231)$ & Dichotomous: 1 = yes, 0 = no \\
\hline $\begin{array}{l}\text { Chronic health conditions } \\
\text { (mean) }\end{array}$ & $0.595(0.020)$ & Number of pain-related, cardiovascular, respiratory, and other chronic disorders: $\min =0, \max =6$ \\
\hline Age (mean) & $51.093(0.440)$ & Years of age: $\min =18, \max =75$ \\
\hline Gender (\%) & $49.213(1.209)$ & Dichotomous: $1=$ female, 0 = male \\
\hline Marital status (\%) & $79.123(1.209)$ & Dichotomous: 1 = married, 0 = other \\
\hline Education (mean) & $7.073(0.092)$ & Years of schooling: $\min =0, \max =20$ \\
\hline Occupation (\%) & $8.767(0.741)$ & Dichotomous: $1=$ professional $/$ managerial, $0=$ other \\
\hline CCP membership (\%) & $6.726(0.636)$ & Dichotomous: 1 = Chinese Communist Party (CCP) member, 0 = not a CCP member \\
\hline Household wealth (mean) & $2.364(0.047)$ & $\begin{array}{l}\text { An index based on ownership of a number of consumer items, such as an LCD TV and a car: min } \\
=0, \max =7\end{array}$ \\
\hline Homeowner (\%) & $85.676(1.461)$ & Dichotomous: 1 = homeowner, 0 = not a homeowner \\
\hline Hukou (\%) & & Categorical: \\
\hline Rural hukou & $84.122(0.756)$ & $0=$ rural hukou (reference) \\
\hline Urban hukou & $6.714(0.522)$ & $1=$ urban hukou \\
\hline Jumin hukou & $9.165(0.569)$ & $2=$ jumin hukou \\
\hline Migration status (\%) & $16.708(1.510)$ & Dichotomous: 1 = cross-town migrant, $0=$ non-migrant \\
\hline $\begin{array}{l}\text { Worry about medical expenses } \\
(\%)\end{array}$ & $69.692(1.029)$ & Dichotomous: $1=$ yes, $0=$ no \\
\hline Worry about elder care (\%) & $67.274(1.018)$ & Dichotomous: 1 = yes, $0=$ no \\
\hline \multicolumn{3}{|c|}{ Notes: $N=3,199.30$ cases with missing data were excluded. } \\
\hline
\end{tabular}

\section{Government effectiveness}

We asked the respondents whether they possessed a local social security card at the time of interview. We aggregated the percentage of local social security cardholders at the PSU level and used it as the measure of local government effectiveness in the analysis. The percentage of cardholders in PSUs ranged from 1.25 to 97.53 , with an average of 46.04 and a standard deviation of 29.43 .

\section{Township/county-level covariates}

To control the variations of local economic development, we collected GDP data at the county level from 2014 to 2017 (in 2014 the National New-Type Urbanization Plan was implemented, and 2017 was the year before the household survey was undertaken). We included the natural logarithm of GDP per capita in 2014 and the percentage of GDP growth from 2014 to 2017 in the analysis. To address the effects of survey sampling design, we also took into account whether the townships were in newly urbanized areas (vs. potential sites of urbanization) and whether the townships were in localities participating in the 2014 Pilot Program. Table 2 presents descriptive statistics and variable descriptions of township/county-level measures. 
Table 2

Descriptive statistics of county/township-level variables

\begin{tabular}{|c|c|c|}
\hline Variables & $\begin{array}{l}\text { Means or } \\
\text { percentages }\end{array}$ & Variable descriptions \\
\hline $\begin{array}{l}\text { Percentage of social security cardholders in } \\
\text { PSUs (mean) }\end{array}$ & $46.039(29.425)$ & Percentage of social security cardholders in PSUs; $\min =1.250, \max =97.531$ \\
\hline County GDP per capita in 2014 (RMB, mean) & $60,048(36,946)$ & County GDP per capital in RMB; $\min =8,998 ; \max =181,370$ \\
\hline County GDP per capita in 2014 (In, mean) & $10.809(0.659)$ & Natural logarithm of county GDP per capital in RMB; $\min =9.105, \max =12.108$ \\
\hline County GDP growth $2014-2017$ (mean) & $28.268(9.324)$ & Percentage of county GDP growth from 2014 to $2017 ; \min =8.934, \max =46.274$ \\
\hline Townships in newly urbanized areas (\%) & 80.000 & $\begin{array}{l}\text { Dichotomous; } 1=\text { townships in newly urbanized areas, } 0=\text { townships that are } \\
\text { potential sites of urbanization }\end{array}$ \\
\hline Townships in the 2014 Pilot Program (\%) & 50.000 & $\begin{array}{l}\text { Dichotomous; } 1 \text { = townships in the } 2014 \text { Pilot Program, } 0 \text { = townships not in the Pilo } \\
\text { Program }\end{array}$ \\
\hline
\end{tabular}

\section{Analytical strategies}

Because the data have a hierarchical structure with level-one units (individuals) nested in level-two units (SSUs), which, in turn, are nested in level-three units (PSUs), we estimated three-level mixed-effects models with random intercepts, allowing each PSU to have its own intercept and each SSU to have its own intercept relative to the PSU in which it was nested.

Our dependent variable was K10 psychological distress. We used it as a continuous variable and estimated generalized linear regressions. To test the direct effect of local government effectiveness on residents' psychological distress, we estimated six models. In Model 1, we only included individual-level covariates. In Model 2 and Model 3, we added the dichotomously coded individual social security cardholder and the percentage of social security cardholders in PSUs, respectively. Both variables were then included in Model 4. In Model 5, we controlled medical and pension insurance at the individual level. Finally, in Model 6, we added the township/county-level covariates. The regression results are reported in Table 3. 
Table 3

Three-level mixed-effects models on psychological distress

\begin{tabular}{|c|c|c|c|c|c|c|}
\hline & Model 1 & Model 2 & Model 3 & Model 4 & Model 5 & Model 6 \\
\hline \multicolumn{7}{|l|}{ Township/county-level variables } \\
\hline \multirow[t]{2}{*}{ Social security cardholders in PSUs } & & & $-1.119 * \star \star$ & $-0.885^{\star \star \star}$ & $-0.727 * \star$ & $-0.719 * \star$ \\
\hline & & & $(0.218)$ & $(0.241)$ & $(0.235)$ & $(0.272)$ \\
\hline \multirow[t]{2}{*}{ County GDP per capita in 2014 (In) } & & & & & & $-0.523 \star \star$ \\
\hline & & & & & & $(0.184)$ \\
\hline \multirow[t]{2}{*}{ County GDP growth 2014-2017 } & & & & & & -0.016 \\
\hline & & & & & & $(0.151)$ \\
\hline \multirow[t]{2}{*}{ Townships in newly urbanized areas } & & & & & & 0.834 \\
\hline & & & & & & $(0.506)$ \\
\hline \multirow[t]{2}{*}{ Townships in the 2014 Pilot Program } & & & & & & 0.072 \\
\hline & & & & & & $(0.446)$ \\
\hline \multicolumn{7}{|l|}{ Individual-level variables } \\
\hline \multirow[t]{2}{*}{ Social security cardholder } & & $-1.204 \star \star$ & & $-0.887 *$ & -0.708 & -0.711 \\
\hline & & $(0.399)$ & & $(0.413)$ & $(0.435)$ & $(0.435)$ \\
\hline \multirow[t]{2}{*}{ Medical insurance } & & & & & -0.797 & -0.769 \\
\hline & & & & & $(0.716)$ & $(0.711)$ \\
\hline \multirow[t]{2}{*}{ Pension insurance } & & & & & $-1.045^{\star}$ & $-1.045^{\star}$ \\
\hline & & & & & $(0.472)$ & $(0.470)$ \\
\hline \multirow[t]{2}{*}{ Chronic health conditions } & $1.999 \star \star \star$ & 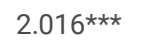 & $2.033^{\star \star *}$ & $2.040 * \star \star$ & $2.048^{\star \star *}$ & $2.042^{\star \star \star}$ \\
\hline & $(0.173)$ & $(0.167)$ & $(0.172)$ & $(0.168)$ & $(0.169)$ & $(0.171)$ \\
\hline \multirow[t]{2}{*}{ Age } & 2.059 & 2.148 & 1.975 & 2.064 & $2.475^{\star}$ & $2.571^{\star}$ \\
\hline & (1.149) & $(1.170)$ & (1.157) & (1.174) & $(1.172)$ & $(1.173)$ \\
\hline \multirow[t]{2}{*}{ Age (squared) } & $-2.666^{\star}$ & $-2.725^{\star}$ & $-2.598^{*}$ & $-2.656^{\star}$ & $-2.948 * \star$ & $-2.998 * \star$ \\
\hline & $(1.061)$ & $(1.072)$ & $(1.069)$ & $(1.077)$ & $(1.078)$ & $(1.078)$ \\
\hline \multirow[t]{2}{*}{ Female } & $0.580^{\star}$ & $0.550 *$ & $0.587^{\star}$ & $0.566^{\star}$ & $0.554^{\star}$ & $0.574^{*}$ \\
\hline & $(0.272)$ & $(0.273)$ & $(0.269)$ & $(0.270)$ & $(0.269)$ & $(0.271)$ \\
\hline \multirow[t]{2}{*}{ Married } & $-1.185^{\star \star}$ & $-1.216^{\star \star}$ & $-1.210 \star \star$ & $-1.225^{\star \star}$ & $-1.185^{\star \star}$ & $-1.192^{\star \star}$ \\
\hline & $(0.413)$ & $(0.411)$ & $(0.413)$ & $(0.411)$ & $(0.415)$ & $(0.422)$ \\
\hline \multirow[t]{2}{*}{ Years of schooling } & $-0.664^{\star \star}$ & $-0.603^{\star \star}$ & $-0.635^{\star \star}$ & $-0.594 \star *$ & $-0.543^{*}$ & $-0.502^{\star}$ \\
\hline & $(0.210)$ & $(0.217)$ & $(0.210)$ & $(0.216)$ & $(0.215)$ & $(0.209)$ \\
\hline \multirow[t]{2}{*}{ Professional/managerial occupation } & 0.286 & 0.277 & 0.298 & 0.285 & 0.315 & 0.301 \\
\hline & $(0.576)$ & $(0.578)$ & $(0.570)$ & $(0.572)$ & $(0.570)$ & $(0.574)$ \\
\hline \multirow[t]{2}{*}{ CCP member } & -0.597 & -0.492 & -0.542 & -0.476 & -0.424 & -0.440 \\
\hline & $(0.587)$ & $(0.596)$ & $(0.579)$ & $(0.588)$ & $(0.595)$ & $(0.605)$ \\
\hline \multirow[t]{2}{*}{ Household wealth } & $-1.189 * \star \star$ & $-1.143^{\star * *}$ & $-1.216^{\star \star \star}$ & $-1.168^{\star \star \star}$ & $-1.130 * * *$ & $-1.131^{\star * \star}$ \\
\hline & $(0.179)$ & $(0.179)$ & $(0.172)$ & $(0.171)$ & $(0.171)$ & $(0.171)$ \\
\hline \multirow[t]{2}{*}{ Homeowner } & $-2.193^{\star \star}$ & $-2.099 * \star$ & $-2.209 * \star$ & $-2.134^{\star \star}$ & $-2.105^{\star \star}$ & $-2.142^{\star *}$ \\
\hline & $(0.754)$ & $(0.764)$ & $(0.730)$ & $(0.743)$ & $(0.735)$ & $(0.736)$ \\
\hline
\end{tabular}

Note: Data were weighted. Standardized coefficients are reported. Robust standard errors are in parentheses.

${ }^{*} p<0.05, * \star p<0.01, * \star * p<0.001$ 


\begin{tabular}{|c|c|c|c|c|c|c|}
\hline & Model 1 & Model 2 & Model 3 & Model 4 & Model 5 & Model 6 \\
\hline \multirow[t]{2}{*}{ Urban hukou } & 0.114 & 0.349 & 0.138 & 0.290 & 0.460 & 0.442 \\
\hline & $(0.486)$ & $(0.490)$ & $(0.494)$ & $(0.491)$ & $(0.498)$ & $(0.500)$ \\
\hline \multirow[t]{2}{*}{ Jumin hukou } & $-1.117 \star \star$ & $-0.971^{\star}$ & $-0.942^{*}$ & $-0.883^{\star}$ & $-0.810^{\star}$ & -0.784 \\
\hline & $(0.421)$ & $(0.420)$ & $(0.395)$ & $(0.406)$ & $(0.390)$ & $(0.405)$ \\
\hline \multirow[t]{2}{*}{ Cross-town migrants } & -1.076 & -1.194 & -1.049 & -1.147 & $-1.242^{*}$ & -1.157 \\
\hline & $(0.605)$ & $(0.634)$ & $(0.612)$ & $(0.636)$ & $(0.617)$ & $(0.616)$ \\
\hline \multirow[t]{2}{*}{ Constants } & $19.750 * \star \star$ & $20.244^{\star \star \star}$ & $19.762^{\star \star \star}$ & $20.123^{\star \star \star}$ & $21.276^{\star \star \star}$ & $20.560 * \star \star$ \\
\hline & $(0.799)$ & $(0.807)$ & $(0.728)$ & $(0.748)$ & $(0.932)$ & $(1.044)$ \\
\hline \multicolumn{7}{|l|}{ Random-effects parameters } \\
\hline \multirow[t]{2}{*}{ Var (county/township) } & $2.033^{\star \star \star}$ & $1.457^{\star \star}$ & 0.743 & 0.789 & 0.596 & 0.242 \\
\hline & $(0.613)$ & $(0.556)$ & $(0.408)$ & $(0.424)$ & $(0.394)$ & $(0.373)$ \\
\hline \multirow[t]{2}{*}{ Var (neighbourhood / county/township) } & $2.884^{\star \star}$ & $2.997 \star \star$ & $2.869 * \star$ & $2.950 \star \star$ & $2.910 * \star$ & $2.914^{\star \star}$ \\
\hline & $(0.991)$ & $(1.023)$ & $(0.985)$ & $(1.006)$ & $(1.008)$ & $(1.006)$ \\
\hline \multicolumn{7}{|l|}{ ICC } \\
\hline County/township & 0.040 & 0.029 & 0.015 & 0.016 & 0.012 & 0.005 \\
\hline Neighbourhood / county/township & 0.094 & 0.088 & 0.072 & 0.075 & 0.071 & 0.064 \\
\hline \multicolumn{7}{|l|}{ Observations } \\
\hline Number of county/townships & 40 & 40 & 40 & 40 & 40 & 40 \\
\hline Number of neighbourhoods & 159 & 159 & 159 & 159 & 159 & 159 \\
\hline Number of respondents & 3,199 & 3,199 & 3,199 & 3,199 & 3,199 & 3,199 \\
\hline Log pseudo likelihood & -10682.531 & -10674.916 & -10673.175 & -10669.256 & -10661.232 & -10657.244 \\
\hline \multicolumn{7}{|c|}{ Note: Data were weighted. Standardized coefficients are reported. Robust standard errors are in parentheses. } \\
\hline${ }^{\star} p<0.05, * * p<0.01, * \star * p<0.001$ & & & & & & \\
\hline
\end{tabular}

To test the mediating effects of micro-worries, we further estimated logistic regression models first with "worry about medical expense" as the dependent variable and then with "worry about elder care" as the dependent variable. The individual-and township/county-level covariates remained the same as Model 6 in Table 3. We then added the two measures of worries to the model on psychological distress, first separately and then together. Table 4 presents results from the estimated regressions. Model 1 in Table 4 is identical to Model 6 in Table 3 but is included for ease of reference. 
Table 4

Three-level mixed-effects models on psychological distress and worries

\begin{tabular}{|c|c|c|c|c|c|c|}
\hline & Model 1 & Model 2 & Model 3 & Model 4 & Model 5 & Model 6 \\
\hline & $\begin{array}{l}\text { Psychological } \\
\text { distress }\end{array}$ & $\begin{array}{l}\text { Worry about medical } \\
\text { expenses }\end{array}$ & $\begin{array}{l}\text { Worry about } \\
\text { elder care }\end{array}$ & $\begin{array}{l}\text { Psychological } \\
\text { distress }\end{array}$ & $\begin{array}{l}\text { Psychological } \\
\text { distress }\end{array}$ & $\begin{array}{l}\text { Psychological } \\
\text { distress }\end{array}$ \\
\hline \multicolumn{7}{|l|}{$\begin{array}{l}\text { Township/county-level } \\
\text { variables }\end{array}$} \\
\hline \multirow{2}{*}{$\begin{array}{l}\text { Social security cardholders } \\
\text { in PSUs }\end{array}$} & $-0.719 * \star$ & $-0.440 *$ & $-0.674^{\star \star}$ & $-0.563^{*}$ & $-0.500 *$ & $-0.475^{\star}$ \\
\hline & $(0.272)$ & $(0.204)$ & $(0.230)$ & $(0.243)$ & $(0.243)$ & $(0.238)$ \\
\hline \multirow{2}{*}{$\begin{array}{l}\text { County GDP per capita in } \\
2014 \text { (In) }\end{array}$} & $-0.523^{\star *}$ & -0.159 & -0.144 & $-0.466^{\star}$ & $-0.465^{\star}$ & $-0.447 *$ \\
\hline & $(0.184)$ & $(0.158)$ & $(0.182)$ & $(0.192)$ & $(0.184)$ & $(0.191)$ \\
\hline \multirow{2}{*}{$\begin{array}{l}\text { County GDP growth 2014- } \\
2017\end{array}$} & -0.016 & $0.338^{*}$ & 0.393 & -0.150 & -0.138 & -0.188 \\
\hline & $(0.151)$ & $(0.171)$ & $(0.223)$ & $(0.154)$ & $(0.141)$ & $(0.152)$ \\
\hline \multirow{2}{*}{$\begin{array}{l}\text { Townships in newly } \\
\text { urbanized areas }\end{array}$} & 0.834 & -0.691 & -0.675 & $1.085^{\star}$ & $1.022^{\star}$ & $1.134^{*}$ \\
\hline & $(0.506)$ & $(0.470)$ & $(0.579)$ & $(0.519)$ & $(0.503)$ & $(0.520)$ \\
\hline \multirow{2}{*}{$\begin{array}{l}\text { Townships in the } 2014 \text { Pilot } \\
\text { Program }\end{array}$} & 0.072 & 0.149 & 0.227 & 0.014 & -0.061 & -0.047 \\
\hline & $(0.446)$ & $(0.381)$ & $(0.443)$ & $(0.445)$ & $(0.435)$ & $(0.445)$ \\
\hline \multicolumn{7}{|l|}{ Individual-level variables } \\
\hline \multirow{2}{*}{$\begin{array}{l}\text { Worry about medical } \\
\text { expenses }\end{array}$} & & & & $2.671^{\star \star \star}$ & & $2.035^{\star \star \star}$ \\
\hline & & & & $(0.381)$ & & $(0.449)$ \\
\hline \multirow[t]{2}{*}{ Worry about elder care } & & & & & $2.308 * \star \star$ & $1.319 * \star \star$ \\
\hline & & & & & $(0.338)$ & $(0.400)$ \\
\hline \multirow[t]{2}{*}{ Social security cardholder } & -0.711 & $-0.335^{\star}$ & $-0.413^{\star \star}$ & -0.597 & -0.561 & -0.541 \\
\hline & $(0.435)$ & $(0.145)$ & $(0.148)$ & $(0.423)$ & $(0.426)$ & $(0.423)$ \\
\hline \multirow[t]{2}{*}{ Medical insurance } & -0.769 & 0.131 & -0.126 & -0.824 & -0.725 & -0.782 \\
\hline & $(0.711)$ & $(0.237)$ & $(0.197)$ & $(0.686)$ & $(0.710)$ & $(0.690)$ \\
\hline \multirow[t]{2}{*}{ Pension insurance } & $-1.045^{\star}$ & 0.120 & -0.010 & $-1.086^{*}$ & $-1.022^{*}$ & $-1.063^{\star}$ \\
\hline & $(0.470)$ & $(0.154)$ & $(0.143)$ & $(0.450)$ & $(0.455)$ & $(0.446)$ \\
\hline \multirow[t]{2}{*}{ Chronic health conditions } & $2.042^{\star \star \star}$ & $0.325^{\star \star \star}$ & $0.383^{\star \star \star}$ & $1.906^{\star \star *}$ & $1.899 * \star \star$ & $1.856^{\star \star \star}$ \\
\hline & $(0.171)$ & $(0.050)$ & $(0.053)$ & $(0.175)$ & $(0.170)$ & $(0.174)$ \\
\hline \multirow[t]{2}{*}{ Age } & $2.571^{\star}$ & $1.885^{\star \star \star}$ & $2.002^{\star \star \star}$ & 1.760 & 1.814 & 1.525 \\
\hline & $(1.173)$ & $(0.331)$ & $(0.511)$ & $(1.243)$ & $(1.225)$ & $(1.257)$ \\
\hline \multirow[t]{2}{*}{ Age (squared) } & $-2.998^{\star *}$ & $-2.154^{\star \star \star}$ & $-2.271^{\star * *}$ & -2.066 & -2.145 & -1.804 \\
\hline & $(1.078)$ & $(0.315)$ & $(0.495)$ & $(1.136)$ & $(1.124)$ & $(1.152)$ \\
\hline \multirow[t]{2}{*}{ Female } & $0.574^{*}$ & 0.173 & -0.063 & 0.514 & $0.604^{*}$ & $0.545^{\star}$ \\
\hline & $(0.271)$ & $(0.107)$ & $(0.092)$ & $(0.269)$ & $(0.268)$ & $(0.268)$ \\
\hline \multirow[t]{2}{*}{ Married } & $-1.192^{\star *}$ & 0.097 & -0.164 & $-1.230 \star \star$ & $-1.134^{\star *}$ & $-1.186^{\star *}$ \\
\hline & $(0.422)$ & $(0.157)$ & $(0.160)$ & $(0.406)$ & $(0.414)$ & $(0.404)$ \\
\hline \multirow[t]{2}{*}{ Years of schooling } & $-0.502^{\star}$ & 0.055 & -0.011 & $-0.526^{*}$ & $-0.511 *$ & $-0.525^{\star}$ \\
\hline & $(0.209)$ & $(0.063)$ & $(0.071)$ & $(0.215)$ & $(0.208)$ & $(0.213)$ \\
\hline
\end{tabular}

Note: Data were weighted. Standardized coefficients are reported. Robust standard errors are in parentheses.

* $p<0.05, * * p<0.01, * * * p<0.001$ 


\begin{tabular}{|c|c|c|c|c|c|c|}
\hline & Model 1 & Model 2 & Model 3 & Model 4 & Model 5 & Model 6 \\
\hline \multirow{2}{*}{$\begin{array}{l}\text { Professional/managerial } \\
\text { occupation }\end{array}$} & 0.301 & -0.295 & -0.187 & 0.494 & 0.411 & 0.509 \\
\hline & $(0.574)$ & $(0.170)$ & $(0.225)$ & $(0.552)$ & $(0.555)$ & $(0.545)$ \\
\hline \multirow[t]{2}{*}{ CCP member } & -0.440 & -0.376 & -0.076 & -0.233 & -0.393 & -0.257 \\
\hline & $(0.605)$ & $(0.235)$ & $(0.250)$ & $(0.568)$ & $(0.587)$ & $(0.565)$ \\
\hline \multirow[t]{2}{*}{ Household wealth } & $-1.131^{\star \star \star}$ & $-0.370 \star \star \star$ & $-0.338 * \star \star$ & $-0.958 * \star \star$ & 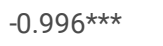 & $-0.919 \star \star \star$ \\
\hline & $(0.171)$ & $(0.066)$ & $(0.066)$ & $(0.168)$ & $(0.168)$ & $(0.169)$ \\
\hline \multirow[t]{2}{*}{ Homeowner } & $-2.142^{\star \star}$ & -0.379 & -0.439 & $-1.984^{\star \star}$ & $-1.992^{\star \star}$ & $-1.934^{\star \star}$ \\
\hline & $(0.736)$ & $(0.319)$ & $(0.339)$ & $(0.678)$ & $(0.737)$ & $(0.693)$ \\
\hline \multicolumn{7}{|l|}{ Hukou (ref.: Rural hukou) } \\
\hline \multirow[t]{2}{*}{ Urban hukou } & 0.442 & 0.159 & -0.134 & 0.347 & 0.439 & 0.366 \\
\hline & $(0.500)$ & $(0.271)$ & $(0.180)$ & $(0.434)$ & $(0.505)$ & $(0.449)$ \\
\hline \multirow[t]{2}{*}{ Jumin hukou } & -0.784 & $-0.431^{\star}$ & -0.229 & -0.580 & -0.707 & -0.590 \\
\hline & $(0.405)$ & $(0.213)$ & $(0.255)$ & $(0.402)$ & $(0.374)$ & $(0.393)$ \\
\hline \multirow[t]{2}{*}{ Cross-town migrants } & -1.157 & -0.436 & 0.124 & -1.012 & $-1.255^{\star}$ & -1.104 \\
\hline & $(0.616)$ & $(0.275)$ & $(0.240)$ & $(0.594)$ & $(0.596)$ & $(0.586)$ \\
\hline \multirow[t]{2}{*}{ Constants } & 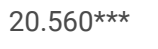 & $1.997^{\star \star}$ & $2.535^{\star \star}$ & $18.411^{\star \star \star}$ & $18.615^{\star \star \star}$ & $17.806^{\star \star \star}$ \\
\hline & $(1.044)$ & $(0.681)$ & $(0.779)$ & $(0.981)$ & $(1.031)$ & $(0.996)$ \\
\hline \multicolumn{7}{|l|}{ Random-effects parameters } \\
\hline \multirow[t]{2}{*}{ Var (county/township) } & 0.242 & $0.732^{\star}$ & $1.096^{\star \star}$ & 0.401 & 0.224 & 0.390 \\
\hline & $(0.373)$ & $(0.301)$ & $(0.383)$ & $(0.427)$ & $(0.433)$ & $(0.458)$ \\
\hline \multirow{2}{*}{$\begin{array}{l}\text { Var (neighborhood | } \\
\text { county/township) }\end{array}$} & 2.914 ** & $0.430 *$ & $0.231^{*}$ & $2.582^{\star \star}$ & $2.811^{\star \star}$ & $2.619 * *$ \\
\hline & $(1.006)$ & $(0.167)$ & $(0.096)$ & $(0.900)$ & $(1.003)$ & $(0.920)$ \\
\hline \multicolumn{7}{|l|}{ ICC } \\
\hline County/township & 0.005 & 0.164 & 0.237 & 0.008 & 0.005 & 0.008 \\
\hline $\begin{array}{l}\text { Neighbourhood I } \\
\text { county/township }\end{array}$ & 0.064 & 0.261 & 0.287 & 0.062 & 0.063 & 0.063 \\
\hline \multicolumn{7}{|l|}{ Observations } \\
\hline $\begin{array}{l}\text { Number of } \\
\text { county/townships }\end{array}$ & 40 & 40 & 40 & 40 & 40 & 40 \\
\hline Number of neighbourhoods & 159 & 159 & 159 & 159 & 159 & 159 \\
\hline Number of respondents & 3,199 & 3,199 & 3,199 & 3,199 & 3,199 & 3,199 \\
\hline Log pseudo likelihood & -10657.244 & -1581.6751 & -1540.9434 & -10616.83 & -10627.357 & -10609.250 \\
\hline \multicolumn{7}{|c|}{ Note: Data were weighted. Standardized coefficients are reported. Robust standard errors are in parentheses. } \\
\hline${ }^{\star} \mathrm{p}<0.05, * \star p<0.01, * \star * \mathrm{p}<$ & 01. & & & & & \\
\hline
\end{tabular}

\section{Results}

\section{Local government effectiveness and psychological distress}

As shown in Table 3, the percentage of local social security cardholders in PSUs is negatively associated with individual psychological distress in Models 3 through 6, which indicates that the more effective the local government is in distributing the cards, the lower the psychological distress of the respondents. The coefficient slightly decreases from Model 4 to Model 5 after controlling for individual medical and pension insurance. At the individual level, cardholder status only shows a negative association with psychological distress in Model 2 and Model 4 before individual medical and pension insurance are controlled.

Model 6 shows that, among township- and county-level covariates, the logarithm of county GDP per capita in 2014 is negatively associated with respondents' psychological distress, which suggests that residents in localities with higher economic development reported better mental health status. However, the 
association between county GDP growth between 2014 and 2017 and individual psychological distress is very minor and not statistically significant.

At the individual level, enrolment in a pension scheme but not a medical insurance scheme appears to be associated with psychological distress. Chronic health conditions are strongly associated with psychological distress; age shows a reversed U-shaped association; and women reported higher distress. On the other hand, being married, higher education, household wealth, and homeownership are all associated with lower psychological distress.

\section{Mediating effects through reducing worries}

As shown in Table 4, the percentage of local social security cardholders in PSUs is negatively associated with worry about medical expenses (standardized coefficient $=-0.440, p<0.05$ ) in Model 2 and worry about elder care (standardized coefficient $=0.674, p<0.01$ ) in Model 3 . Models 4 and Model 5 confirm that worry about medical expenses (standardized coefficient $=2.671, p<0.001$ ) and worry about elder care (standardized coefficient $=2.308, p<0.001$ ) are strongly associated with psychological distress.

We followed Baron and Kenny's protocol to determine the existence and extent of a mediating effect on the relationship between local government effectiveness and individual psychological distress as a result of worries about medical expenses and elder care [55-57]. Adding worry about medical expenses in Model 4 reduces the standardized coefficient on the percentage of local social security cardholders from -0.719 ( $p<0.01)$ to -0.563 ( $p<0.05$ ). The proportion of total effect that is mediated is 0.676 . The Aroian version of the Sobel test yields z-value $=2.043$ and $p$-value $=0.041$. Similarly, adding worry about elder care in Model 5 reduces the standardized coefficient on percentage of local social security cardholders from $-0.719(p<0.01)$ to -0.500 ( $p<0.05$ ). The proportion of total effect that is mediated is 0.755 . The Aroian version of the Sobel test further yields $z$-value $=2.669$ and $p$-value $=0.008$. These results indicate that the mediating effect is statistically significant, particularly in the case of worry about elder care. Finally, when both worry about medical expenses and worry about elder care are included in Model 6, the standardized coefficient on percentage of local social security cardholders in PSUs further decreases to $-0.475(p<0.05)$, while the standardized coefficients on other township/county and individual covariates remain stable.

\section{Robustness checks}

To check the model specifications, we estimated three-level mixed-effects regressions with additional covariates. We included county public expenses per capita in 2014 and the growth of county public expense from 2014 to 2017 to take into account the fiscal capacity of local government. We used the number of medical beds per 10,000 residents in the county in 2014 as well as the percentage increase in medical beds in the county from 2014 to 2017 as measures of local service infrastructure. None of these additional covariates appeared to be significant in the estimated models, nor did the standardized coefficients on other variables change significantly. We therefore did not include these covariates in the models reported. The regression models and results are available upon request.

\section{Conclusion And Discussion}

Drawing on data from a national survey $(\mathrm{N}=3,229)$ in 40 localities undergoing rural-urban transition in China, we investigated both the direct and indirect impact of local government effectiveness on residents' psychological distress. Local government effectiveness was measured by the level of access to the social security system through the distribution of social security cards among citizens. We estimated three-level mixed-effects models to test our hypotheses that respondents residing in localities with higher government effectiveness will report lower psychological distress and that a negative association between local government effectiveness and residents' psychological distress will be mediated by reducing micro-worries related to social security. Although people can be more or less stressed and worried regardless of the type of problems that they encounter [47], after controlling for individual attributes and allowing for random intercepts at neighbourhood and township/county levels, our results still demonstrate that effective local governments significantly reduce residents' psychological distress and their worries about medical expenses and elder care. Both our research hypotheses were confirmed.

The results indicate that, to reduce residents' worries and psychological distress during the process of rural-urban transition, it is essential to improve local government effectiveness, particularly in promoting residents' access to the social security system. The Chinese social security card system is a striking case in point. Huge variations exist across localities. Places where residents have a higher level of access to social services show better mental health outcomes. Some localities may lack the resources necessary to implement the system themselves. Financial and technological support should be allocated to these localities so that residents have the same access to relevant services.

The findings also provide evidence that local government effectiveness in reducing residents' psychological distress was mediated by alleviation of their worries about medical expenses and elder care. As China continues to implement the human-centred National New-Type Urbanization Plan, our research demonstrates that issues related to health and elder care are extremely important and should be a priority for both central and local governments.

A caveat in the analysis needs to be noted before we conclude. Although we observed a direct association between worries and psychological distress, it is also likely that higher levels of psychological distress can worsen attitudes about life and amplify worries [48]. The relationship between worries and psychological distress requires further investigation to disentangle how worries may influence psychological distress and vice versa.

\section{Declarations}

Acknowledgements

Not applicable 
All authors contributed to the study conception and design. Material preparation was conducted by LG. Data collection were performed by JC. Data analysis was performed by LG, SX, and JC, and discussed and approved by all authors. The first draft of the manuscript was written by LG and revised by JC and SX. All authors commented on previous versions of the manuscript and approved the final manuscript.

\section{Funding}

The 2018 Urbanization and Quality of Life Survey was funded by the Hong Kong Research Grants Council General Research Fund (PolyU 156637/16H) and the Li \& Fung China Social Policy Research Fund. The research undertaken for this article was also supported by the Departmental General Research Fund from Department of Applied Social Sciences, The Hong Kong Polytechnic University (Project ID: P0033440).

\section{Availability of data and materials}

The datasets used and/or analysed during the current study are available from the corresponding author on reasonable request.

\section{Ethics approval and consent to participate}

This study was performed in line with the principles of the Declaration of Helsinki. Approval was granted by the Ethics Committee of the Hong Kong Polytechnic University.

\section{Consent for publication}

Written informed consent was obtained from participants whose case studies were featured in the study.

\section{Competing interests}

The authors state that there is no conflict of interest.

\section{References}

1. Peen J, Dekker J, Schoevers RA, et al (2007) Is the prevalence of psychiatric disorders associated with urbanization? Soc Psychiatry Psychiatr Epidemiol 42:984-989. https://doi.org/10.1007/s00127-007-0256-2

2. Ventriglio A, Torales J, Castaldelli-Maia JM, et al (2020) Urbanization and emerging mental health issues. CNS Spectr 1-8. https://doi.org/10.1017/S1092852920001236

3. Chen J, Chen S, Landry PF, Davis DS (2014) How dynamics of urbanization affect physical and mental health in Urban China. China Q $220: 988-1011$. https://doi.org/10.1017/S0305741014001465

4. Guan X, Wei H, Lu S, et al (2018) Assessment on the urbanization strategy in China: Achievements, challenges and reflections. Habitat Int 71:97-109. https://doi.org/10.1016/j.habitatint.2017.11.009

5. Chen J (2018) Some people may need it, but not me, not now: Seeking professional help for mental health problems in urban China. Transcult Psychiatry 55:754-774. https://doi.org/10.1177/1363461518792741

6. Li W, Reavley N (2020) Recognition and beliefs about treatment for mental disorders in mainland China: A systematic review and meta-analysis. Soc Psychiatry Psychiatr Epidemiol 55:129-149

7. Fukuyama F (2016) Governance: What Do We Know, and How Do We Know It? Annual Reviews Inc.

8. Helliwell JF, Huang H, Grover S, Wang S (2018) Empirical linkages between good governance and national well-being. J Comp Econ 46:1332-1346. https://doi.org/10.1016/j.jce.2018.01.004

9. Teorell J, Dahlberg S, Holmberg S, et al (2020) The Quality of Government Standard Dataset, version Jan 20. Gothenburg

10. Bank W (2019) Worldwide Governance Indicators (WGI). https://info.worldbank.org/governance/wgi/

11. Sacks A, Levi M (2010) Measuring government effectiveness and its consequences for social welfare in sub-Saharan African countries. Soc Forces 88:2325-2351. https://doi.org/10.1353/sof.2010.0044

12. Amahazion FJ (2015) Human trafficking: the need for human rights and government effectiveness in enforcing anti-trafficking. Glob Crime 16:167-196. https://doi.org/10.1080/17440572.2015.1019613

13. Ortega B, Sanjuán J, Casquero A (2017) Determinants of efficiency in reducing child mortality in developing countries. The role of inequality and government effectiveness. Health Care Manag Sci 20:500-516. https://doi.org/10.1007/s10729-016-9367-1

14. Helliwell JF, Huang H (2008) How's your government? International evidence linking good government and well-being. Br J Polit Sci 38:595-619. https://doi.org/10.1017/S0007123408000306

15. Liu H, Gao H, Huang Q (2020) Better government, happier residents? Quality of government and life Satisfaction in China. Soc Indic Res 147:971-990. https://doi.org/10.1007/s11205-019-02172-2

16. Peiró-Palomino J, Picazo-Tadeo AJ, Rios V (2020) Well-being in European regions: Does government quality matter? Pap Reg Sci 99:555-582. https://doi.org/10.1111/pirs.12494

17. Erlingsson G, Lundåsen SW (2019) When state-level institutions cannot tell the whole story: An inquiry into municipal variations in quality of government. Governance gove.12463. https://doi.org/10.1111/gove.12463 
18. Woo C (2018) Good governance and happiness: Does technical quality of governance lead to happiness universally in both rich and poor countries? J Int Area Stud 25:37-56

19. Diener E, Oishi S, Lucas RE (2015) National accounts of subjective well-being. American Psychological Association Inc.

20. Ritchie H, Roser M (2020) Urbanization

21. United Nations. (2015) Sustainable Development Goals - Goal 11: Make cities inclusive, safe, resilient and sustainable. https://www.un.org/sustainabledevelopment/cities/

22. Cheru $F$ (2005) Globalization and uneven urbanization in Africa: the limits to effective Urban governance in the provision of basic services. Los Angeles

23. Harpham T, Boateng KA (1997) Urban governance in relation to the operation of urban services in developing countries. Habitat Int 21:65-77. https://doi.org/10.1016/S0197-3975(96)00046-X

24. Jones H, Clench B, Harris D (2014) The governance of urban service delivery in developing countries: Literature review. London

25. te Lintelo DJH, Gupte J, McGregor JA, et al (2018) Wellbeing and urban governance: Who fails, survives or thrives in informal settlements in Bangladeshi cities? Cities 72:391-402. https://doi.org/10.1016/j.cities.2017.10.002

26. Cartier C (2015) Territorial urbanization and the party-state in China. Territ Polit Gov 3:294-320. https://doi.org/10.1080/21622671.2015.1005125

27. Hsing Y tien (2010) The Great Urban Transformation: Politics of Land and Property in China

28. Ma LJC (2005) Urban administrative restructuring, changing scale relations and local economic development in China. Polit Geogr 24:477-497. https://doi.org/10.1016/j.polgeo.2004.10.005

29. China NB of S (2020) National Data on Administrative Divisions. http://data.stats.gov.cn/easyquery.htm?cn=C01\&zb=A0101\&sj=2018. Accessed 6 Nov 2020

30. Wang F-L (2005) Organizing Through Division And Exclusion: China's Hukou System. Stanford University Press, Palo Alto, CA

31. Solinger DJ (1999) Contesting citizenship in urban China: Peasant migrants, the state, and the logic of the market. University of California Press, Berkeley

32. Chen J, Davis DS, Landry PF (2017) Beyond Hukou Reform: Enhancing Human-Centered Urbanization in China

33. Wang X-R, Hui EC-M, Choguill C, Jia S-H (2015) The new urbanization policy in China: Which way forward?

34. Zheng $Y$ (2019) Urbanization to fuel rural revitalization

35. Li B, Chen C, Hu B (2016) Governing urbanization and the New Urbanization Plan in China. Environ Urban 28:515-534. https://doi.org/10.1177/0956247816647345

36. Ong LH (2014) State-led urbanization in China: Skyscrapers, land revenue and concentrated villages. China Q 217:162-179. https://doi.org/10.1017/S0305741014000010

37. Daily C China's social security card goes digital. http://www.chinadaily.com.cn/a/201804/23/WS5addbf5da3105cdcf6519fae.html. Accessed 6 Nov 2020

38. Chen AJ, Pan SL, Zhang J, et al (2009) Managing e-government implementation in China: A process perspective. Inf Manag 46:203-212. https://doi.org/10.1016/j.im.2009.02.002

39. People.cn (2018) The number of China's social security card holders has reached 11.5 billion

40. Security CM of HR and S (2014) Opinions of the Ministry of Human Resources and Social Security on Accelerating the Application of Social Security Cards.

http://www.mohrss.gov.cn/SYrlzyhshbzb/zhuanti/jinbaogongcheng/jbgcshehuibaozhangka/jbgcshbzkwenjianbiaozhun/201408/t20140807_137962.htr Accessed 6 Nov 2020

41. Chen A, Huang W (2015) China's E-Government. In: Pan SL (ed) Managing Organizational Complexities with Digital Enablement in China: A Casebook. World Scientific, Singapore, pp 97-106

42. Li Y, Shang H (2020) Service quality, perceived value, and citizens' continuous-use intention regarding e-government: Empirical evidence from China. Inf Manag 57:103197. https://doi.org/10.1016/j.im.2019.103197

43. Sujarwoto S, Tampubolon G (2015) Decentralisation and Citizen Happiness: A Multilevel Analysis of Self-rated Happiness in Indonesia. J Happiness Stud 16:455-475. https://doi.org/10.1007/s10902-014-9518-3

44. Whiteley P, Clarke HD, Sanders D, Stewart MC (2010) Government performance and life satisfaction in contemporary Britain. J Polit 72:733-746. https://doi.org/10.1017/S0022381610000137

45. Commission CND and R National New Urbanization Comprehensive Pilot Program. [2014] No. 1229.

46. Tian X (2010) Loneliness A psychological turning point in the reconstruction of the urban order in China. Soc Sci China 31:147-164

47. Boehnke K, Fuß D, Rupf M (2001) Values and Well-Being: The Mediating Role of Worries'. Soc Psychol (Gott) 55:293-301

48. Luciano M, De Rosa C, Del Vecchio V, et al (2016) Perceived insecurity, mental health and urbanization: Results from a multicentric study. Int J Soc Psychiatry 62:252-261. https://doi.org/10.1177/0020764016629694

49. lacus SM, King G, Porro G (2012) Causal inference without balance checking: Coarsened exact matching. Polit Anal 20:1-24. https://doi.org/10.1093/pan/mpr013

50. Landry PF, Shen M (2005) Reaching migrants in survey research: The use of the global positioning system to reduce coverage bias in china. Polit Anal 13:1-22. https://doi.org/10.1093/pan/mpi001

51. Statistics. CNB of (2015) Tabulation on the 2010 Population Census of the People's Republic of China. China Statistical Press, Beijing 
52. Shen YC, Zhang MY, Huang YQ, et al (2006) Twelve-month prevalence, severity, and unmet need for treatment of mental disorders in metropolitan China. Psychol Med 36:257-267. https://doi.org/10.1017/S0033291705006367

53. Chen J (2011) Internal migration and health: Re-examining the healthy migrant phenomenon in China. Soc Sci Med 72:1294-1301. https://doi.org/10.1016/j.socscimed.2011.02.016

54. Chen J, Zhu S (2016) Online Information Searches and Help Seeking for Mental Health Problems in Urban China. Adm Policy Ment Heal Ment Heal Serv Res 43:535-545. https://doi.org/10.1007/s10488-015-0657-6

55. Baron RM, Kenny DA (1986) The moderator-mediator variable distinction in social psychological research: Conceptual, strategic, and statistical considerations. J Pers Soc Psychol 51:1173-1182. https://doi.org/10.1037//0022-3514.51.6.1173

56. MacKinnon DP, Lockwood CM, Hoffman JM, et al (2002) A comparison of methods to test mediation and other intervening variable effects. Psychol Methods 7:83-104. https://doi.org/10.1037/1082-989X.7.1.83

57. Preacher KJ (2020) Calculation for the Sobel Test - An interactive calculation tool for mediation tests. http://quantpsy.org/sobel/sobel.htm 